\title{
Alat Deteksi Tingkat Stres Manusia Berbasis Android Berdasarkan Suhu Tubuh, Heart Rate dan Galvanic Skin Response (GSR)
}

\author{
Wahyu Tri Bakti, Nanda Kurnia Wardati \\ Universitas Muhammadiyah Jember, Jl. Karimata No. 49 Jember 68121 Indonesia \\ (tlp: 0331-226728; fax: 0331-337957) \\ e-mail: nandakurniawardati@unmuhjember.ac.id
}

\begin{abstract}
ABSTRAK
Stres pada manusia memiliki tingkat yang berbeda. Tingkat stres pada manusia dapat diukur dengan alat pendeteksi parameter stres dengan memperhitungkan suhu tubuh, heart rate dan Galvanic Skin Response (GSR). GSR memperhitungkan resistansi kulit dari dua jari tangan. Alat tersebut dapat mengukur level kejenuhan dan ketegangan pada manusia. Analisis data pada penelitian ini menggunakan Atmega8535, DS1820 untuk mengetahui temperatur tubuh, Pulse Sensor untuk mengetahui heart rate, serta alumunium foil untuk mengetahui nilai resistansi kulit dari dua jari tangan. Data diperoleh melalui sensor pada setiap parameter yang diukur, setelah itu data dikirim ke Gadget Android melalui komunikasi Bluetooth. Hasil analisis data kemudian dibandingkan dengan nilai tingkat stres manusia usia dewasa muda. Hasil perbandingan tersebut menampilkan kondisi tingkat stres pada manusia yang ditampilkan pada Gadget Android. Kemudian dari hasil tersebut akan dibandingkan dengan hasil pengujian stres yang dilakukan oleh dokter psikiater. Berdasarkan hasil pengukuran dan perbandingan didapatkan persentase keberhasilan sebesar $40 \%$.
\end{abstract}

Kata kunci: Stres, Atmega8535, Pulse Sensor, Heart Rate, GSR, Temperatur Tubuh, DS1820, Psikiater.

Copyright (C) 2019 Universitas Muhammadiyah Jember.

\section{PENDAHULUAN}

Perkembangan sistem operasi pada handphone telah mengalami peningkatan. Sebagaimana yang sudah kita ketahui saat ini seperti iOs, PalmOs, Symbian, Java, dan Android. Android merupakan sistem yang sedang dikembangkan oleh Google dan sedang popular di kalangan masyarakat. Sistem android tersebut dapat mendukung fitur touch screen dan fitur canggih lainnya. Menurut hasil survey yang telah dilakukan oleh perusahaan riset dan teknologi informasi ternama (Gartner), menyatakan bahwa terjadi peningkatan pangsa pasar terhadap android, dimana dalam tahun 2010 terjadi peningkatan lebih dari $700 \%$. Angka tersebut diperoleh dari smartphone yang terjual dengan nominal 67.224.500. Hal ini menunjukkan bahwa android mempunyai potensi yang besar di masa depan [1].

Stres dapat disebabkan oleh berbagai macam hal. Sumber stres pada manusia diantaranya adalah stres yang didapat dari lingkungan pendidikan, stres karena pendapatan, stres karena pekerjaan, serat tipe kepribadian dan cara berpikir yang menyebabkan stres [2].

Stres pada manusia merupakan bagian normal dalam kehidupan sehari-hari. Hal tersebut sering kali dialami oleh manusia, namun masih dalam kondisi yang tidak selalu buruk. Stres bahkan menjadi motivasi yang dibutuhkan manusia untuk selalu aktif dan mendapatkan energi. Namun disisi lain, stres yang berlebihan dan stres yang tidak dapat ditangani dapat menimbulkan perasaan yang tidak nyaman.

Sehingga perlu memiliki kemampuan untuk mengelola stres. Tanda-tanda reaksi stres pada manusia terjadi pada reaksi fisik. Reaksi tersebut seperti Increased heart rate, elevated blood pressure, dan cold hands. Stres meliputi empat kondisi yaitu tegang ( $\mathrm{s}=\mathrm{stressed})$, cemas ( $\mathrm{t}=$ tense), tenang (c=calm) dan rileks ( $\mathrm{r}=$ relaxed) [2].

Alat pendeteksi stres manusia pada penelitian ini merupakan pengembangan dari alat yang pernah dibuat oleh Andri Zita, salah satu mahasiswa Institut Teknologi Sepuluh Nopember dalam tugas akhirnya yang berjudul "Alat Pendeteksi Stress Menggunakan GSR dan Detak Jantung". Perbaikan yang dilakukan dalam pembuatan alat ini adalah penambahan subyek yang di ukur yaitu suhu tubuh, 
dan juga perbaikan dalam metode penampilan data. Dikarenakan subyek yang diukur dalam alat yang pernah dibuat tersebut hanya sebatas mengukur Heartrate dan GSR, maka dalam pembuatan alat ini ditambahkan pengukuran subyek baru berupa Suhu Tubuh. Penampilan data yang digunakan menggunakan LCD 16x2, membuat data yang ditampilkan kurang menarik dan terbatas pada penampilan data saja maka penampil data yang digunakan dalam pembuat alat ini adalah Gadget Android yang mana data yang ditampilkan dapat diolah dan dapat disimpan.

\section{KAJIAN PUSTAKA}

\subsection{Mikrokontroler ATMega 8535}

Mikrokontroller Automatic Voltage Regulator (AVR) adalah bagian dari mikrokontroler yang dikeluarkan oleh Atmel dan memiliki arsitektur Reduced Instruction Set Computing (RISC) untuk meningkatkan kecepatan, ukuran program dan penggunaan catu daya. AVR dapat menggabungkan fast access register file dan intruksi dengan sekali jalan dengan 32-register x 8-bit. 32-register AVR dapat melakukan eksekusi instruksi dengan sekali jalan. Hal inilah yang membuat AVR relatif lebih cepat jika dibandingkan dengan mikrokontroler 8-bit lainnya. 6 dari 32-register yang ada dapat digunakan sebagai indirect address register pointer 16-bit yang memungkinkan penghitungan alamat data space yang efisien. AVR memiliki kecepatan 0 sampai 16Mhz. AVR yang sudah ditambahkan beberapa alat dapat mencapai kecepatan hingga 20Mhz [3].

\subsection{Bluetooth}

Bluetooth merupakan Personal Area Network (PAN) tanpa kabel. Bluetooth dapat saling terhubung dan dapat digunakan sebagai alat sharing informasi antar satu alat dengan alat yang lainnya. Bluetooth dapat beroperasi dalam pita frekuensi 2,4Ghz dengan menggunakan sebuah frequency hopping traceiver yang dapat menyediakan layanan komunikasi data dan suara secara real time. Namun kelemahan yang terdapat pada bluetooth ini adalah memiliki jangkaua yang terbatas dan terkesan pendek, serta memiliki kemampuan transfer data yang cenderung lambat [4].

\subsection{Galvhanic Skin Response (GSR)}

Galvhanic Skin Response (GSR) merupakan ukuran dari konduktansi antara dua elektroda. Konduktansi kulit dianggap sebagai fungsi dari aktivitas kelenjar keringat dan pori-pori kulit. Walau konduktansi kulit seseorang dapat dipengaruhi oleh berbagai keadaan, diantaranya adalah jenis kelamin, golongan darah, kulit dan situasi. Aktivitas kelenjar keringat sebagian dikendalikan oleh sistem saraf simpatik. Jika terjadi kecemasan maka akan terjadi peningkatan cepat dalam konduktansi kulit. Semakin seseorang cemas, maka nilai resistansi tubuhnya akan semakin besar.

Galvhanic Skin Respond terdiri dari 2 lembar alumunium foil yang dapat terhubung kerangkaian menggunakan kabel. Sensor pada GSR dapat digunakan sebagai penangkap sinyal listrik yang terdapat pada kulit tangan. Sensor GSR juga berpacu pada kemampuan konduktivitas kulit. Jenis logam yang digunakan pada sensor ini berpengaruh terhdap sensitifitas dari penangkapan sinyal listrik tersebut [5].

\subsection{Heart Rate Sensor}

Heart Rate Sensor terdiri dari rangkaian pemancar dan rangkaian penerima. Rangkaian pemancar (transmitter) sendiri terdiri dari resistor sebagai pembatas arus dan LED infrared. Sedangkan rangkaian penerima (receiver) terdiri dari resistor sebagai pembatas arus dan photodiode. Hal ini kemudian diteruskan ke rangkaian filter, penguat dan mikrokontroler untuk dilakukan pengolahan lebih lanjut. Gambar 1 menunjukkan prinsip kerja daripada Heart Rate Sensor. 


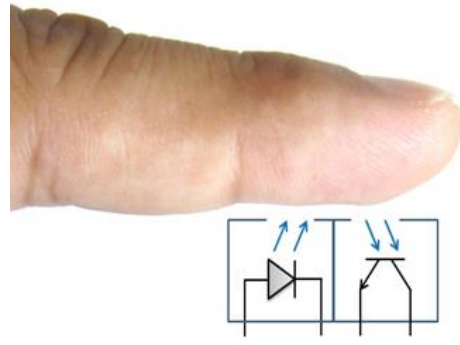

Gambar 1. Heart Rate Sensor

Heart Rate Sensor digunakan untuk mengetahui perubahan detak jantung yang dibantu dengan band pass filter untuk mendapatkan sinyal denyut jantung pada setiap menit. Hasil deteksi detak jantung akan dikirim kerangkaian $\mathrm{ADC}$ untuk dijadikan data digital dan dilakukan pengolahan dalam mikrokontroler [6].

\subsection{DS 1820}

Suhu tubuh pada manusia dapat diukur melalui dua jenis sensor, yaitu LM35 dan DS1820. Terdapat perbedaan terhadap tingkat keakuratan pada sensor LM35 dan DS1820. Sensor DS1820 memiliki fungsi seperti termometer dan terdapat sistem alarm dengan 9-bit sampai 12-bit. Sensor DS1820 dapat mengukur suhu tubuh pada kisaran $-55^{\circ} \mathrm{C}$ hingga $125^{\circ} \mathrm{C}$ dan dapat bekerja secara akurat dengan tingkat kesalahan kurang lebih $0,5^{\circ} \mathrm{C}$ pada kisaran $-10^{\circ} \mathrm{C}$ hingga $85^{\circ} \mathrm{C}$. Selain itu, daya yang digunakan pada DS1820 dapat diperoleh dari data line secara langsung (parasite power). Oleh sebab itus tidak perlu menggunakan listrik eksternal [7].

Rangkaian pada sensor DS1820 dengan 64-bit memiliki keunikan yang memungkinkan DS1820 dapat terhubung kebeberapa fungsi dan melalui satu kabel yang sama. Sehingga 1 microprocessor saja dapat digunakan untuk mengendalikan sensor dalam jumlah yang banyak, yang kemudian dapat dipindahkan ke daerah yang lebih luas. Fitur yang terdapat pada aplikasi ini meliputi sistem untuk mengontrol lingkungan, sistem untuk memantau suhu tubuh di dalam bangunan, peralatan, sistem untuk proses monitoring dan sistem kontrol.

\section{METODE PENELITIAN}

\subsection{Perancangan Alat}

Prinsip kerja pada penelitian ini adalah sebagai berikut.

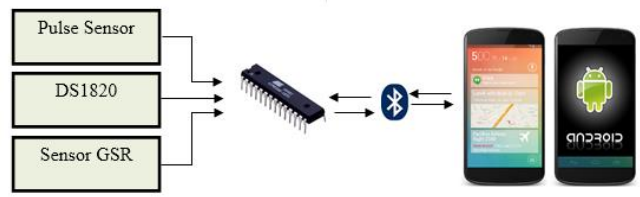

Gambar 2. Blok Diagram Sistem

Sistem kerja dari blok diagram seperti pada gambar 2 di atas adalah pertama sensor pulsa akan mendeteksi detak jantung, kemudian DS1820 akan mendeteksi suhu tubuh dan sensor GSR akan mendeteksi resistansi pada kulit manusia. Data diolah sehingga menjadi data berupa angka, kemudian data dikirimkan kepada Gadget Android melalui komunikasi Bluetooth.

Data yang diterima oleh perangkat Android tersebut akan diolah dengan cara dibandingkan dan dilakukan penentuan keputusan menggunakan metode If-If sehingga didapatkan hasil berupa keputusan yang dapat dijadikan hasil akhir dam mendeteksi tingkat stres pada manusia.

\subsection{Perancangan Perangkat Keras}

Perangkat keras yang dibuat pada alat ini terdiri dari sistem minimum mikrokontroler Atmega8535 sebagai tempat dudukan mikrokontroler dan pengolah serta dilengkapi rangkaian sensor GSR sebagai pendeteksi resistansi kulit, sensor DS1820 sebagai pendeteksi suhu, rangkaian 
photo reflector sebagai sensor heartrate rangkaian catu daya sebagai pengatur tegangan perangkat keras yang akan dirancang untuk skripsi ini terdiri dari empat bagian, yaitu catu daya, minimum sistem Atmega8535, rangkaian sensor GSR, dan rangkaian sensor Heart Rate.

\section{HASIL PENGUJIAN DAN PEMBAHASAN}

\subsection{Pengujian Sensor Heart Rate}

Pengujian ini bertujuan untuk mengetahui keakuratan dan error dari sensor Heart Rate. Pengujian dilakukan dengan membandingakan sensor Heart Rate dengan alat tensimeter digital Omron HEM-7203 yang biasa digunakan di apotek.

Tabel 1. Pengujian Sensor Heart Rate

\begin{tabular}{cccc}
\hline No & $\begin{array}{l}\text { Heart Rate } \\
(\mathrm{bpm})\end{array}$ & $\begin{array}{l}\text { Omron HEM- } \\
\text { 7203 }(\mathrm{bpm})\end{array}$ & $\begin{array}{l}\text { Error } \\
(\%)\end{array}$ \\
\hline 1 & 78 & 77 & 1,299 \\
2 & 80 & 81 & 1,235 \\
3 & 86 & 84 & 2,381 \\
4 & 82 & 81 & 1,235 \\
5 & 78 & 80 & 2,500 \\
6 & 74 & 77 & 3,896 \\
7 & 90 & 87 & 3,448 \\
8 & 88 & 86 & 2,326 \\
& Error Rata-rata & 2,29 \\
\hline
\end{tabular}

\subsection{Pengujian Sensor Suhu Tubuh}

Pengujian Sensor Suhu dilakukan dengan cara mengukur sample mengguakan sensor suhu alat dan Termometer Digital OMRON MC-245, kemudian dari hasil pengukuran akan dilakukan perbandingan hasil pengukuran antara kedua sensor tersebut, namun sebelum dilakukan pengukuran langkah pertama yang harus dilakukan adalah mengukur kecepatan respon antara sensor suhu alat dan Thermometer Digital Omron MC-245 agar diketahui tingkat respon dari tiap sensor terhadap waktu pengukuran.

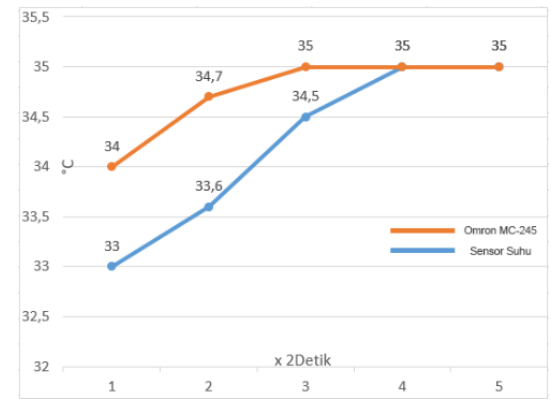

Gambar 3. Perbandingan Respon antara Sensor Suhu Alat dan Thermometer Digital Omron MC-245

Tabel 2. Pengujian Sensor Suhu Tubuh

\begin{tabular}{lccc}
\hline No & $\begin{array}{l}\text { Sensor } \\
\text { Suhu Alat }\end{array}$ & $\begin{array}{l}\text { Thermometer Digital } \\
\text { Omron MC-245 }\end{array}$ & Error \\
\hline 1 & 36 & 36,8 & 2,174 \\
2 & 36 & 36,8 & 2,174 \\
3 & 36,54 & 36,9 & 0,976 \\
4 & 36,44 & 36,9 & 1,247 \\
5 & 36,5 & 36,9 & 1,084 \\
6 & 37,6 & 37,8 & 0,529 \\
7 & 37 & 37,3 & 0,804 \\
8 & 37,6 & 37,8 & 0,529 \\
9 & 35,8 & 36 & 0,556 \\
10 & 35,8 & 36 & 0,556 \\
\multicolumn{3}{c}{ Error Rata-rata } \\
\hline
\end{tabular}




\subsection{Pengujian Sensor Galvhanic Skin Respond (GSR)}

Pengujian sensor Galvhanic Skin Respond dilakukan dengan cara meletakkan beberapa nilai resistor pada sensor GSR, selanjutnya dapat diketahui nilai konduktansi dari beberapa tahanan tersebut yang kemudian dibandingkan dengan nilai hitung bedasarkan rumus yang digunakan.

Tabel 3. Pengujian Sensor Suhu Tubuh

\begin{tabular}{lcccc}
\hline No & $\begin{array}{l}\text { Nilai } \\
\text { Resistor } \\
(\text { Ohm })\end{array}$ & $\begin{array}{l}\text { Nilai Resistansi } \\
\text { Hitung } \\
(\mu \text { Siemens })\end{array}$ & $\begin{array}{l}\text { Nilai Resistansi } \\
\text { Ukur }(\mu \text { Siemens })\end{array}$ & Error \\
\hline 1 & $1 \mathrm{~K}$ & 1000,00 & 1149,43 & 0,15 \\
2 & $2 \mathrm{~K}$ & 500,00 & 526,32 & 0,05 \\
3 & $3 \mathrm{~K}$ & 333,33 & 357,14 & 0,07 \\
4 & $4,7 \mathrm{~K}$ & 212,77 & 211,09 & 0,01 \\
5 & $10 \mathrm{~K}$ & 100,00 & 101,01 & 0,01 \\
6 & $20 \mathrm{~K}$ & 50,00 & 51,51 & 0,03 \\
7 & $22 \mathrm{~K}$ & 45,45 & 46,30 & 0,02 \\
8 & $100 \mathrm{~K}$ & 10,00 & 10,20 & 0,02 \\
9 & $200 \mathrm{~K}$ & 5,00 & 5,28 & 0,06 \\
10 & $270 \mathrm{~K}$ & 3,70 & 3,68 & 0,01 \\
& \multicolumn{5}{c}{ Error Rata-rata } \\
\hline
\end{tabular}

\subsection{Pengujian Keseluruhan Alat}

Pengujian secara keseluruhan terhadap alat yang digunakan pada penelitian ini dilakukan untuk melihat tingkat kesuksesan dari alat yang dirancang. Pengujian dilakukan dengan cara membandingkan hasil dari pengukuran alat dengan hasil dari pengukuran manual yang dilakukan oleh seorang dokter psikologi. Kemudian dari hasil perbandingan tersebut akan didapatkan apakah alat yang dibuat bisa digunakan sebagai alat pendeteksi tingkat stres manusia.

Tabel 4. Pengujian Alat Keseluruhan

\begin{tabular}{llll}
\hline No & Stres Detektor & Manual & Hasil \\
\hline 1 & Cemas & Normal & Tidak \\
& & Nesuai \\
2 & Cemas & Normal & $\begin{array}{l}\text { Tidak } \\
\text { Sesuai }\end{array}$ \\
& & Normal & Tidak \\
3 & Stress & & Sesuai \\
& & Stress & Sesuai \\
4 & Stress & Normal & Sesuai \\
\hline
\end{tabular}

Berdasarkan hasil perbandingan diatas kemudian akan dihitug nilai atau persentase nilai keberhasilan dari alat yang telah dibuat. Berikut adalah persentase nilai keberhasilan alat stres detektor.

Tabel 5. Presentase Nilai Keberhasilan Alat Stres Detektor

\begin{tabular}{llll}
\hline $\begin{array}{l}\text { Banyak } \\
\text { Data }\end{array}$ & Sesuai & Tidak Sesuai & $\begin{array}{l}\text { Persentase } \\
\text { Keberhasilan }\end{array}$ \\
\hline 5 & 2 & 3 & $40 \%$ \\
\hline
\end{tabular}

Berdasarkan persentase keberhasilan, didapatkan persentase keberhasilan sebesar $40 \%$, yang didapat 5 data pengukuran. 


\section{KESIMPULAN}

Penelitian ini melakukan perencanaan dan pembuatan sistem, kemudian dilakukan pengujian dan analisis, maka kesimpulan mengenai sistem kerja dari rangkaian yaitu alat yang dibuat memiliki persentase keberhasilan sebesar $40 \%$ yang diambil dari 5 data sample obyek yang diukur. Saran dari penelitian ini yaitu dapat dikembangkan menggunakan sistem operasi lainnya seperti Windows Phone dan Iphone. Serta perlu adanya perbaikan dengan menambahkan set poin pada saat akan melakukan pengukuran, karena setiap manusi memiliki fisik yang berbeda-beda.

\section{REFERENSI}

[1] Akbarul, H.A., 2010, 24 Jam Pintar Pemrograman Android \#1. Imagineit education Center. Jogjakarta.

[2] Scott, E., 2010, Stress Effect [online] Tersedia di: http://www.stress.about.com/stress-effect.html. Diakses pada 18 Juli 2014.

[3] Iswanto., 2009, Mikrokontroller ATmega8535 dengan Bahasa Basic, Gava. Media, Yogyakarta.

[4] Hermawan, D.F, Setiawan, I, Andromeda, T., 2008, Penggunaan Teknologi Java Pada Sistem Pengendali Peralatan Elektronik Melalui Bluetooth. Teknik Elektro, Universitas Diponegoro. Semarang.

[5] Rokhana, R., 2008, Implementasi Jaringan Syaraf Tiruan pada Analisa Tingkat Emosional Manusia berdasar Data Galvanic Skin Response. EEPIS - ITS, Surabaya.

[6] Scot, W.N, Ipswich, Mass., 1993, Pressure Signal Prosessing Aparatus and Methode for an Automatic Bloodpressure Gauge. United .U.S patent.

[7] Maxim., 2007, DS1820 Econo 1-Wire Digital Thermometer, Revisi 1011072007, Maxim Integrated Product Inc, San Jose, USA.

[8] Suwarto, E., 2012, Alat Pendeteksi Tingkat Stress Manusia Berbasis Atmega16, Politeknik Negeri Semarang. Semarang

[9] Tailor, D.H., 2007, Drivers Galvanic Skin Response and the Risk of Accident, Department of scientific and industrial research - France.

[10] Tamsuri, A., 2006, Tanda-tanda Vital Suhu Tubuh. EGC Emergency Arcan Buku Kedokteran. Jakarta.

\section{BIOGRAFI PENULIS}

\begin{tabular}{|l|l|} 
Wahyu Tri Bakti merupakan mahasiswa di lingkungan Program Studi Teknik \\
Elektro Universitas Muhammadiyah Jember.
\end{tabular}

